\title{
A Short Growing Season Negatively Affects Progeny Vigor in Jointed Goatgrass (Aegillops cylindrica)
}

\author{
Lynn M. Ingegneri*, Michael P. Quinn, Andrew G. Hulting, Carol A. Mallory-Smith \\ Department of Crop and Soil Science, Oregon State University, Corvallis, USA \\ Email: "lynn.ingegneri@oregonstate.edu
}

Received 20 February 2015; accepted 6 March 2015; published 12 March 2015

Copyright (C) 2015 by authors and Scientific Research Publishing Inc.

This work is licensed under the Creative Commons Attribution International License (CC BY). http://creativecommons.org/licenses/by/4.0/

(c) (i) Open Access

\section{Abstract}

Seed production and germination in jointed goatgrass were negatively affected by a shorter vernalization period in field studies conducted at Oregon State University. Our objective was to determine if a shorter growing season experienced by a maternal jointed goatgrass plant similarly affected seedling vigor in the progeny. Seed mass, percent germination, emergence, seedling height and biomass, including roots, were recorded or evaluated on progeny that were produced from three jointed goatgrass populations grown under a long or short growing season in a common garden experiment in eastern Oregon, an area where jointed goatgrass is known to commonly infest natural resources, including winter wheat. Seeds produced under a shorter growing season weighed less, were slower to germinate, and displayed lower percent germination compared with seeds produced under a long growing season. Seedlings from a short growing season were slower to emerge, and produced less shoot biomass compared to seedlings produced under a long growing season. Seedling roots and shoots were shorter when seeds were produced under a short growing season. A shorter growing season negatively affected jointed goatgrass seedling vigor. If resources for jointed goatgrass management are limited, strategies should focus on controlling plants that emerge in the fall, because they have the potential to produce more vigorous seedlings compared to plants that emerge in late winter or early spring.

\section{Keywords}

Caryopses, Crop Rotation, Germination, Growing Degree Days, Seedling Vigor, Seeds, Vernalization, Winter Annual

\footnotetext{
${ }^{*}$ Corresponding author.
}

How to cite this paper: Ingegneri, L.M., Quinn, M.P., Hulting, A.G. and Mallory-Smith, C.A. (2015) A Short Growing Season Negatively Affects Progeny Vigor in Jointed Goatgrass (Aegilops cylindrica). Agricultural Sciences, 6, 315-324. 


\section{Introduction}

Annual spring-sown crops rotated with winter wheat (Triticum aestivum L.) are commonly recommended as part of an integrated strategy to manage jointed goatgrass in predominantly cereal-based cropping systems. Jointed goatgrass germinates and establishes in the fall; its vegetative and reproductive growth are similar to winter wheat. Spring tillage and herbicide applications control jointed goatgrass plants that establish during the previous fall. Furthermore, a shorter growing season prevents most spring-emerged jointed goatgrass plants from producing seeds within the constraints of an annual cropping system. Jointed goatgrass plants that do not reproduce before the harvest of spring crops are generally destroyed in the process or die from insufficient precipitation in late summer.

The presence of jointed goatgrass plants in advanced reproductive stages within fields planted to spring wheat, spring barley, and spring peas has been recorded, however [1]. Selection for a vernalization insensitive jointed goatgrass biotype to account for these findings was ruled out using populations collected in Oregon and Washington [2]-[5]. However, jointed goatgrass plants may reproduce if minimum conditions for growth and reproductive development are met. Jointed goatgrass plants sown in late February and early March reproduced before the end of the crop year, and these plants were characterized by reduced seed production and germinability [2]. The effect of this shorter growing season on the seedling vigor of the progeny was not studied.

Crop seedling and plant performance are often predicted based on seed quality and its influence on the number of emerged seedlings, the mean time between sowing and seedling emergence, and the length of time to full emergence [6]. Effects of seed quality on seedling growth rate after emergence also have been reported [7]-[9]. Aboveground biomass production has been routinely used to measure a plant's competitive ability [10]. For weed species, such as jointed goatgrass, the rapid production of aboveground biomass serves as a fundamental means of achieving a competitive advantage. Therefore, factors that reduce this ability severely reduce the competitive advantage of jointed goatgrass plants.

Our objective was to measure the components of crop seed quality and seedling vigor-seed mass, percent germination, emergence, seedling height, and seedling biomass—on seeds and seedlings produced from jointed goatgrass plants that were exposed to a shorter growing season compared with a longer or traditional winter wheat growing season.

\section{Materials and Methods}

Spikelets were collected from three jointed goatgrass populations: a roadside (A-R), a winter wheat rotation (B-W), and a spring wheat rotation (C-S) in a previous study on the reproductive development of jointed goatgrass [2]. Jointed goatgrass populations were subjected to either a long or short growing season that was controlled by field planting date. Plants with a long (or traditional) growing season were sown in October, while plants with a short growing season were sown in February. Spikelets from all plants were harvested in July. After analysis of this vernalization experiment, spikelets from each jointed goatgrass population and growing season duration were dissected, and seeds from the secondary florets were excised. The average mass of 300 seeds was recorded using three replicates from each jointed goatgrass population and growing season duration. Recorded values were used to calculate 1000-count seed weights.

Greenhouse Experiments. Twenty-five seeds from each combination of jointed goatgrass population and growing season duration were randomly selected. Seeds were spaced evenly and planted uniformly to a depth of 2.5-cm in a $28 \times 43 \times 6$-cm flat filled with commercial potting medium (Sunshine Mix \#4. Sun Gro Horticulture Distribution Inc. Bellevue, Washington 98008). The flats were arranged randomly in four replicates of six full factorial combinations of jointed goatgrass population $(n=3)$ and growing season duration $(n=2)$, and each replicate was evenly distributed on a greenhouse bench. Daytime temperatures in the greenhouse ranged from $14^{\circ} \mathrm{C}$ to $34^{\circ} \mathrm{C}$, and nighttime temperatures ranged from $13^{\circ} \mathrm{C}$ to $22^{\circ} \mathrm{C}$. Seedlings were watered as needed. Supplemental lighting and fertilization were not necessary due to the short duration of the experiment.

Beginning one day after planting (DAP), flats were observed daily and shoot emergence recorded by seedling. Observations continued until no further emergence was recorded (a range of two to three d). Emergence was defined as the appearance of the coleoptile above the soil surface. Seedling height was recorded daily by seedling for $15 \mathrm{~d}$. Seedlings were then clipped at the soil surface, bulked within a replicate flat, oven dried for 24-h at $50^{\circ} \mathrm{C}$, and weighed. Aboveground biomass per seedling was calculated by dividing the total mass of the seedlings by the number of emerged seedlings per flat. 
Growth Chamber Experiments. Four replications of 25 seeds from each combination of jointed goatgrass population and growing season duration were randomly selected and placed on moistened germination paper inside acrylic boxes (Cont156C Transparent Acrylic Container. Hoffman Manufacturing Inc., International AgriSupply, 353 29th Avenue SW, Albany, OR 97321).The boxes were arranged randomly in four replicates of six full factorial combinations (as described above) and placed in a growth chamber. A $25^{\circ} \mathrm{C} / 15^{\circ} \mathrm{C}$ day/night temperature regime and 12-h photoperiod were maintained in the growth chamber [11]. Observations were made daily for $7 \mathrm{~d}$. Germination was defined as 3-mm of radicle emergence. At the end of $7 \mathrm{~d}$, the seedlings were removed from the germination boxes. Root and shoot lengths were measured. Root and shoot biomass were combined, oven dried at $50^{\circ} \mathrm{C}$ for 48 -h, and weighed.

Statistical Analysis. Experiments were conducted as replicated, randomized designs with a full factorial treatment structure of three populations, two growing season durations, and four replicates unless otherwise specified. Means and standard errors were calculated for seed mass. For greenhouse experiments, percent emergence $1 \mathrm{DAP}$ and $\mathrm{d}$ to $100 \%$ emergence were analyzed using a two-factor analysis of variance, and comparisons of treatment means were performed using a test of least significant difference at $\alpha=0.05$. Daily seedling height was modeled using regression models, and contrasts performed in PROC GLM ([SAS] Statistical Analysis System Version 9.1. Carey, NC, 27513). Aboveground biomass was modeled using PROC MIXED, and treatment comparisons performed using $95 \%$ confidence intervals. In the growth chamber experiments, early and final germination values were compared using means and standard errors. Root and shoot length were analyzed using ANOVA. Several interactions were observed in the preliminary analysis of data in both greenhouse and growth chamber experiments. Due to the variable nature of the interactions, each experimental run was analyzed separately in the final analysis. For analysis of root and shoot lengths by treatment in experiment 1, Tukey's HSD for all pairwise comparisons was performed at $\alpha=0.05$. For experiment 2 , this was not necessary due to the absence of an interaction; therefore, comparisons of treatment means were performed using Fisher's Protected LSD ( $\alpha=$ $0.05)$.

\section{Results and Discussion}

Seed Mass. Seeds produced on plants exposed to a short growing season weighed less than those exposed to a long growing season for all three jointed goatgrass populations (Table 1). Differences in seed mass are most likely due to differing amounts of carbohydrate reserves, given the high final germination values for all seeds (Table 2), and the relatively small contribution the embryo makes to overall seed mass. Seed size is one component of seed vigor and is linked with emergence, seedling health, and fitness in wheat, a closely related species. Lafond and Baker [12] reported a 21\% to $28 \%$ decrease in shoot dry matter for wheat plants derived from small seeds compared with larger seeds. Mian and Nafziger [13] measured a 30\% reduction in shoot weight, root weight, and tiller number on 4-wk-old winter wheat seedlings grown from smaller seeds as compared with those grown from larger seeds. In our study, smaller seeds produced on plants from a short growing season would likely negatively affect early seedling vigor. Seed size does not alter germination, but affects growth, development, and yield in crop plants. Bigger seeds have several advantages when compared to smaller seeds, such as faster seedling growth, greater number of fertile tillers per plant, and greater yield [14]. Crops with larger seeds also have an advantage when the crop is grown under environmental stress, especially drought [13].

Table 1. Average mass in grams for 1000 jointed goatgrass seeds by jointed goatgrass population and growing season duration. Seeds were excised from the secondary floret within the spikelet.

\begin{tabular}{|c|c|c|}
\hline & \multicolumn{2}{|c|}{ Growing season } \\
\hline & Long & Short \\
\hline & \multicolumn{2}{|c|}{ Mean $\pm \mathrm{SE}$} \\
\hline Jointed goatgrass population & \multicolumn{2}{|c|}{----------- g ----------- } \\
\hline A-R & $13.8 \pm 0.3$ & $7.3 \pm 0.0$ \\
\hline B-W & $12.7 \pm 0.7$ & $2.6 \pm *$ \\
\hline C-S & $11.8 \pm 0.1$ & $4.4 \pm 0.4$ \\
\hline
\end{tabular}

*There were only enough seeds for one replicate. 
Table 2. Early and final percent germination values and standard errors (SE) by jointed goatgrass population and growing season duration by experiment.

\begin{tabular}{ccc}
\hline & \multicolumn{2}{c}{ Germination (\%) } \\
\cline { 2 - 3 } Experiment 1 & Mean \pm SE & Day 7 \\
\cline { 2 - 3 } A-R long season & $93 \pm 3.4$ & $100 \pm 0.0$ \\
A-R short season & $78 \pm 4.8$ & $91 \pm 2.5$ \\
B-W long season & $95 \pm 3.0$ & $100 \pm 0.0$ \\
B-W short season & $74 \pm 8.4$ & $95 \pm 2.5$ \\
C-S long season & $100 \pm 0.0$ & $100 \pm 0.0$ \\
C-S short season & $44 \pm 5.9$ & $93 \pm 1.9$ \\
Experiment 2 & & \\
A-R long season & $69 \pm 4.4$ & $100 \pm 0.0$ \\
A-R short season & $52 \pm 5.9$ & $71 \pm 5.5$ \\
B-W long season & $95 \pm 2.5$ & $100 \pm 0.0$ \\
B-W short season & $60 \pm 1.3$ & $94 \pm 2.0$ \\
C-S long season & $87 \pm 4.1$ & $99 \pm 1.0$ \\
C-S short season & $69 \pm 4.4$ & $99 \pm 1.0$ \\
\hline
\end{tabular}

Seedling Germination and Emergence. Seeds produced under a short growing season were slower to germinate, exhibited greater variability in early and final percent germination, and displayed lower total germination compared with seeds from a long growing season (Table 2). In experiment 1, germination values on $\mathrm{d} 2$ for seeds produced under a short growing season ranged from $44 \%$ to $78 \%$, while values for the long growing season were $93 \%$ or greater. By d 7 , germination values for all seeds produced under a short growing season were $91 \%$ or greater, while seeds from the long growing season reached $100 \%$ germination. In experiment 2 , germination values on $\mathrm{d} 2$ for seeds from the short growing season ranged from $52 \%$ to $69 \%$, while values for the long growing season ranged from $69 \%$ to $95 \%$. By d 7 , seeds from the A-R population and short growing season germinated to $71 \%$, while germination values for all other jointed goatgrass populations and growing season durations were $94 \%$ or greater.

Germinability is another component of seed quality that can be used to evaluate seed health and predict seedling vigor. Regular embryo development and sufficient seed reserves are essential for germination and establishment of young seedlings. The high germination values for nearly all jointed goatgrass populations and growing season lengths in this study indicate that jointed goatgrass is capable of producing germinable seeds within a shortened growing season.

Emergence 1 DAP. Jointed goatgrass population and growing season duration affected seedling emergence 1 DAP in both experiments (Table 3). In experiment 1, seedling emergence on d 1 was similar for B-W and C-S populations, and was $40 \%$ and $50 \%$, respectively, while $70 \%$ of seedlings emerged in jointed goatgrass population A-R. Averaged over population, 63\% of seedlings emerged from seed produced in a long growing season, while $44 \%$ of seedlings emerged from seed produced in a short season. In experiment 2 , emergence was similar for A-R and C-S populations, and was $71 \%$ and $78 \%$, respectively, while $58 \%$ of seedlings emerged in jointed goatgrass population B-W. Averaged over population, $84 \%$ of seedlings emerged from seed produced during a long growing season, while $53 \%$ of seedlings emerged from seed produced in the short season. Jointed goatgrass population and growing season were both factors that could explain the variability in emergence; however, the effect of growing season duration was generally equal or more powerful than population (statistical output not shown).

Days to 100\% Emergence. Seedlings emerged from all jointed goatgrass populations and growing season durations within the window of 2 - 6 DAP. The specific number of days to reach $100 \%$ emergence varied with population and growing season duration, and results were not consistent between the experiments (Table 4). A small sample size $(n=4)$ and one observation per day may have led to greater variability in these data; standard 
Table 3. Seedling emergence and statistical grouping one day after planting for jointed goatgrass population and growing season duration by experiment.

\begin{tabular}{|c|c|c|}
\hline Experiment 1 & & \\
\hline Jointed goatgrass population & Emergence (\%) & t Grouping \\
\hline A-R & 70 & A \\
\hline B-W & 40 & B \\
\hline \multirow[t]{2}{*}{ C-S } & 50 & B \\
\hline & \multicolumn{2}{|c|}{$\operatorname{LSD}_{(0.05)}=15$} \\
\hline \multicolumn{3}{|l|}{ Growing season } \\
\hline Long & 63 & A \\
\hline \multirow[t]{2}{*}{ Short } & 44 & B \\
\hline & \multicolumn{2}{|c|}{$\operatorname{LSD}_{(0.05)}=13$} \\
\hline \multicolumn{3}{|l|}{ Experiment 2} \\
\hline \multicolumn{3}{|l|}{ Jointed goatgrass population } \\
\hline A-R & 71 & A \\
\hline B-W & 58 & B \\
\hline \multirow[t]{2}{*}{ C-S } & 78 & A \\
\hline & \multicolumn{2}{|c|}{$\operatorname{LSD}_{(0.05)}=12$} \\
\hline \multicolumn{3}{|l|}{ Growing season } \\
\hline Long & 84 & A \\
\hline \multirow[t]{2}{*}{ Short } & 53 & B \\
\hline & \multicolumn{2}{|c|}{$\operatorname{LSD}_{(0.05)}=10$} \\
\hline
\end{tabular}

Table 4. Days to $100 \%$ emergence and statistical grouping for jointed goatgrass population and growing season duration by experiment.

\begin{tabular}{|c|c|c|}
\hline Experiment 1 & & \\
\hline Jointed goatgrass population & $\begin{array}{l}\text { Days to } 100 \% \\
\text { Emergence }\end{array}$ & t Grouping \\
\hline A-R & 2.9 & A \\
\hline B-W & 4.4 & B \\
\hline C-S & 4.3 & B \\
\hline \multicolumn{3}{|c|}{$\operatorname{LSD}_{(0.05)}=0.90$} \\
\hline \multicolumn{3}{|l|}{ Growing season } \\
\hline Long & 3.6 & A \\
\hline Short & 4.1 & A \\
\hline & \multicolumn{2}{|c|}{ NSD $^{*}$} \\
\hline \multicolumn{3}{|l|}{ Experiment 2} \\
\hline \multicolumn{3}{|l|}{ Jointed goatgrass population } \\
\hline A-R & 3.6 & A \\
\hline B-W & 3.6 & A \\
\hline C-S & 3.1 & A \\
\hline & \multicolumn{2}{|c|}{ NSD } \\
\hline \multicolumn{3}{|l|}{ Growing season } \\
\hline Long & 2.8 & A \\
\hline Short & 4.2 & B \\
\hline & \multicolumn{2}{|c|}{$\mathrm{LSD}_{(0.05)}=0.86$} \\
\hline
\end{tabular}

*No significant difference. 
deviations around the mean were approximately $1 \mathrm{~d}$. Despite these design limitations, in both experiments, all seedlings from seed produced under the long growing season emerged earlier compared to seedlings from the short growing season.

Seedling Height. Jointed goatgrass seedlings that resulted from seeds produced under a long growing season grew faster than seedlings from seeds produced under a short growing season (Figure 1). Contrasts of slope coefficients (statistical output not shown) revealed significant differences in seedling height in response to growing season duration for all jointed goatgrass populations in both experiments. In experiment one, 14 DAP, A-R, B-W, and C-S seedlings that resulted from the long growing season measured 29, 25, and 27-cm compared with 24, 19, and 17-cm, respectively, for the short growing season. Similar data were observed in experiment 2. Steeper slope coefficients for all long growing season plants compared with short growing season plants predicted that this difference would continue to increase with time.

Aboveground Biomass. Averaged over population, jointed goatgrass seedlings from the shorter growing season weighed $46 \%$ and $41 \%$ less compared with seedlings from the longer growing season by experiment (Figure 2). The average aboveground biomass of one jointed goatgrass seedling produced under a long growing season ranged from $60 \mathrm{mg}$ to $97 \mathrm{mg}$ compared with $30 \mathrm{mg}$ to $60 \mathrm{mg}$ produced under a short growing season. In experiment 2, the average mass of a single seedling produced under a long growing season ranged from $48 \mathrm{mg}$ to $70 \mathrm{mg}$ compared with the mass of a seedling produced under a short growing season, $30 \mathrm{mg}$ to $41 \mathrm{mg}$. Jointed goatgrass populations did not vary in their production of shoot biomass in response to growing season duration.

Root and Shoot Lengths. Seedling root and shoot lengths from seeds produced during a long growing season were generally greater when compared with seedlings produced during a short growing season (Table 5). In experiment 1 , an interaction between population and growing season duration was significant $(p \leq 0.0001)$ for root length. Seedlings from the C-S population and short growing season produced shorter roots compared with the A-R and B-W populations. Root lengths ranged from 4.9-cm to 6.4-cm for the long growing season and 2.8-cm to 3.8-cm for the short growing season. There was no interaction for root length between population and growing season duration in experiment 2 , and the effect of population was not significant $(F=1.78 ; p=0.1690)$. Root lengths ranged from $5.6-\mathrm{cm}$ to $6.1-\mathrm{cm}$ for the long growing season and $3.2-\mathrm{cm}$ to $3.8-\mathrm{cm}$ for the short growing season. An interaction between population and growing season duration $(\mathrm{p}<0.0001)$ was observed for shoot length in experiment 1 . Shoots from the B-W population and long growing season measured 7.5-cm compared with $6.2-\mathrm{cm}$ and $5.4-\mathrm{cm}$ in the A-R and C-S populations, respectively. There were no differences among populations for shoot length within the short growing season. There was no interaction in shoot length between populations and growing seasons in experiment 2; however, both main effects were significant. Shoot lengths ranged from $6.9-\mathrm{cm}$ to $7.4-\mathrm{cm}$ for the long growing season and 4.6- $\mathrm{cm}$ to $5.9-\mathrm{cm}$ for the short growing season.

Table 5. Seedling root and shoot length $(\mathrm{cm})$ by jointed goatgrass population and growing season duration for seeds produced under long and short growing seasons.

\begin{tabular}{|c|c|c|c|c|c|c|c|c|}
\hline \multirow[b]{2}{*}{ Jointed goatgrass population } & \multicolumn{7}{|c|}{ Growing Season Duration } & \\
\hline & Long & & Short & & Long & & Short & \\
\hline Experiment 1 & \multicolumn{3}{|c|}{ Root length (cm) } & \multicolumn{5}{|c|}{ Shoot length $(\mathrm{cm})$} \\
\hline A-R & 4.9 & b & 3.3 & C & 6.2 & $\mathrm{~b}$ & 4.7 & C \\
\hline $\mathrm{B}-\mathrm{W}$ & 6.4 & a & 3.8 & $\mathrm{C}$ & 7.5 & $\mathrm{a}$ & 5.3 & C \\
\hline \multirow[t]{2}{*}{ C-S } & 4.9 & $\mathrm{~b}$ & 2.8 & $\mathrm{~d}$ & 5.4 & $\mathrm{C}$ & 4.9 & $\mathrm{C}$ \\
\hline & \multicolumn{7}{|c|}{ Tukey’s $\operatorname{HSD}_{(0.05)}$ for all pairwise comparisons } & \\
\hline \multicolumn{9}{|l|}{ Experiment 2} \\
\hline A-R & 5.6 & $\mathrm{a}$ & 3.5 & $\mathrm{~b}$ & 6.9 & $\mathrm{ab}$ & 5.0 & $\mathrm{bb}$ \\
\hline B-W & 5.9 & $\mathrm{a}$ & 3.8 & $\mathrm{~b}$ & 7.1 & $\mathrm{ab}$ & 4.6 & $\mathrm{bb}$ \\
\hline C-S & 6.1 & $\mathrm{a}$ & 3.2 & $\mathrm{~b}$ & 7.4 & аa & 5.9 & ba \\
\hline & \multirow{2}{*}{\multicolumn{3}{|c|}{$\mathrm{LSD}_{0.05}=0.26$}} & & \multicolumn{4}{|c|}{$\mathrm{LSD}_{0.05}($ dur $)=0.32$} \\
\hline & & & & & \multicolumn{4}{|c|}{$\mathrm{LSD}_{0.05}($ popln $)=0.39$} \\
\hline
\end{tabular}



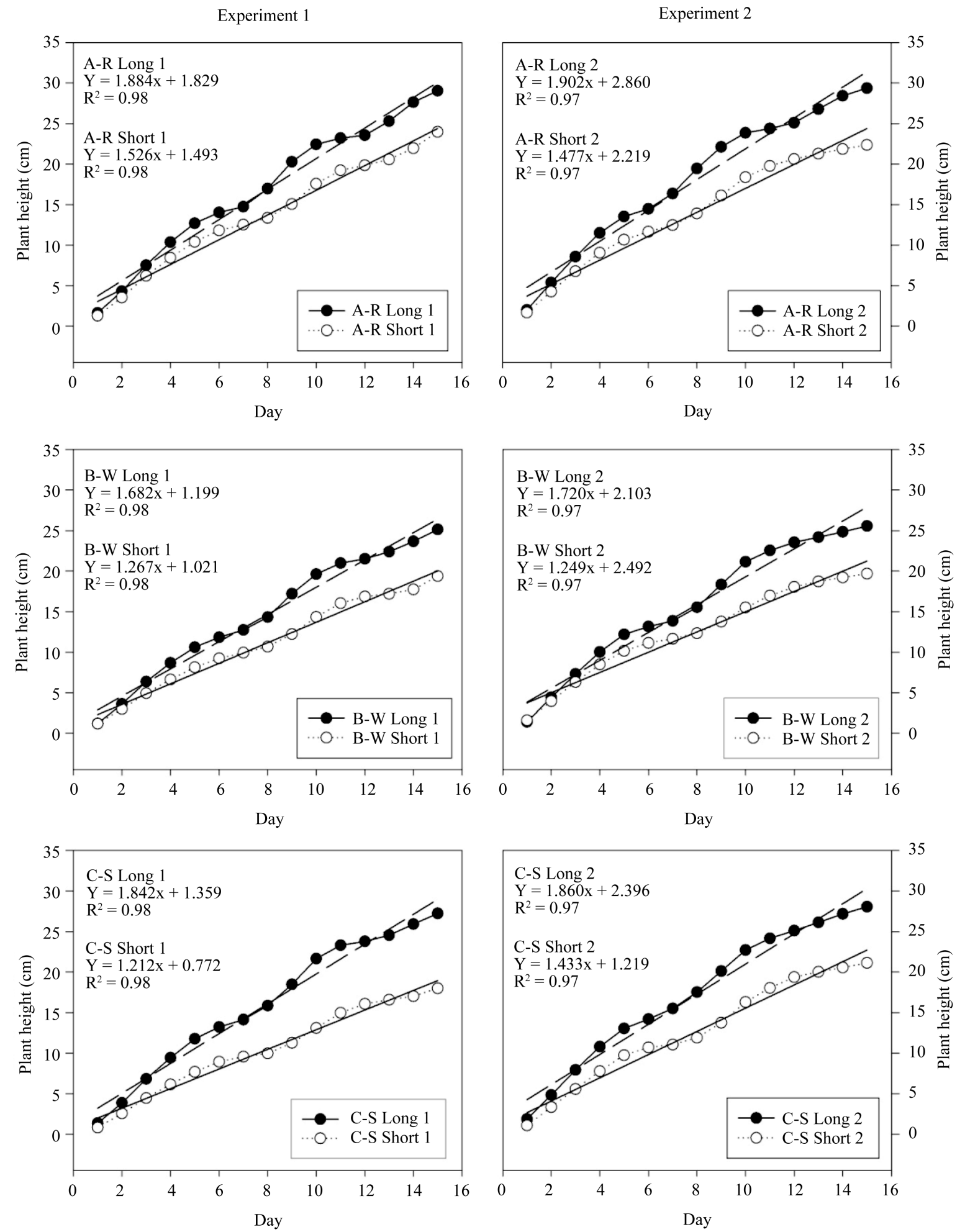

Figure 1. Mean daily height in centimeters by jointed goatgrass population and growing season fitted to linear regression lines with equations and associated $\mathrm{R}^{2}$ values from two greenhouse experiments.

Root and Shoot Biomass. The combined biomass of roots and shoots 7 DAP was negatively affected by the shorter growing season. In experiments 1 and 2, biomass was reduced 52\% and 46\%, respectively (Figure 3 ). In 


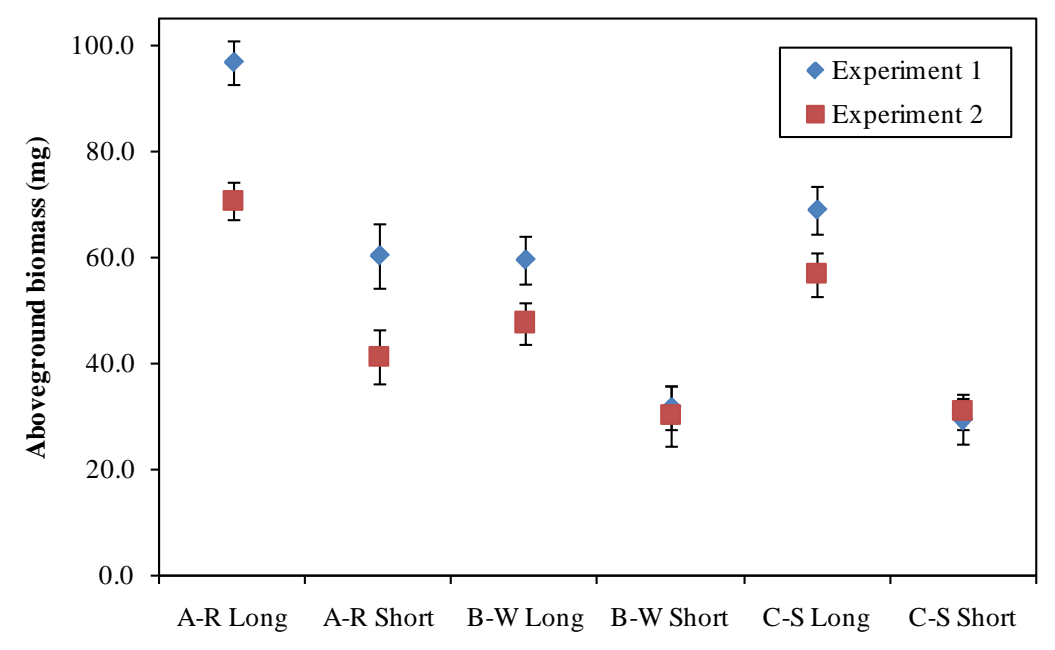

Jointed goatgrass populations and growing season durations

Figure 2. Aboveground biomass (mean $\pm 95 \%$ confidence interval) produced by three jointed goatgrass populations and two growing seasons from two greenhouse experiments.

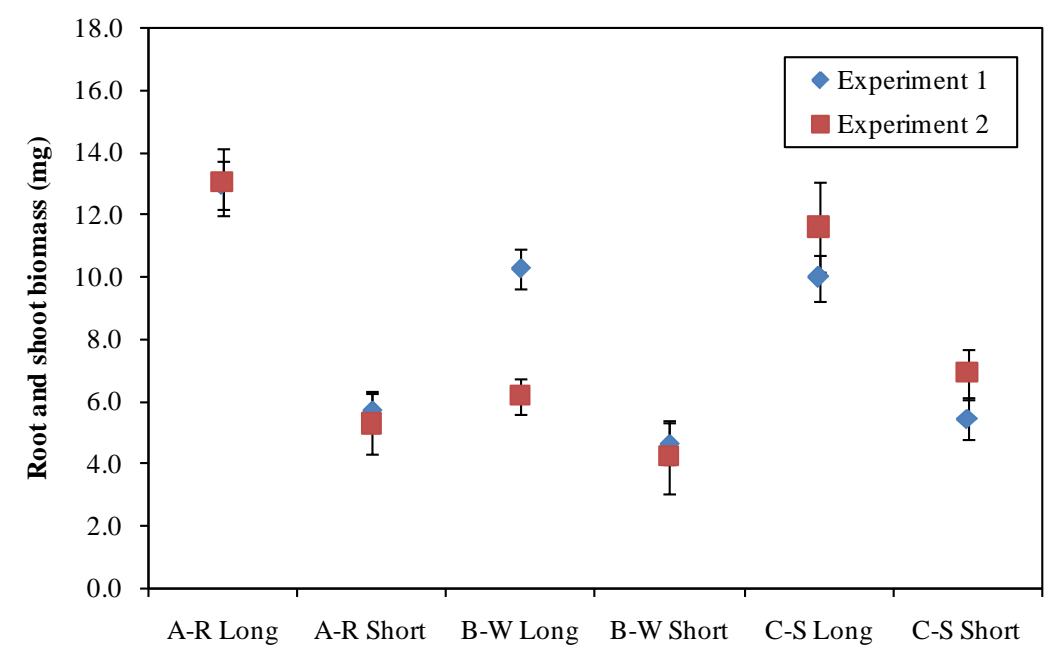

Jointed goatgrass populations and growing season durations

Figure 3. Combined root and shoot biomass (mean $\pm 95 \%$ confidence interval) produced by three jointed goatgrass populations and two growing seasons from two growth chamber experiments.

experiment 1, the combined average mass of shoots and roots for a seed produced under the long growing season was $11.1 \mathrm{mg}$ compared with $5.3 \mathrm{mg}$ produced under the short growing season. Results were similar for experiment 2 . An interaction between population and growing season duration was significant in experiment $1(\mathrm{p}=$ $0.0003)$ and experiment $2(\mathrm{p}<0.0001)$, which indicated that the reduction in dry weight due to the shortening of the growing season varied by jointed goatgrass population. In experiment 1 , seedlings produced from seeds of the A-R jointed goatgrass population and long growing season produced more total dry weight compared with seedlings from the B-W and C-S populations. In experiment 2, differences were observed among the mean dry weights produced by jointed goatgrass population and a short growing season. Seeds from the C-S population produced more dry weight followed by those from the A-R and B-W populations. Seeds of the B-W population and long growing season produced less dry weight than those from either the A-R or C-S populations. However, as was the case in the greenhouse experiments, more of the variation in the growth response could be attributed to growing season duration rather than population (statistical output not shown). Additionally, seeds from a 
shortened growing season produced a greater number of abnormal seedlings, having either a root or a shoot within $7 \mathrm{~d}$, but not both (Quinn, personal observation).

Seedlings in the greenhouse were grown under optimal conditions and adequately spaced to eliminate the effects of interspecific competition. A major criticism of greenhouse studies examining the effect of seedling size is that without competition, a plant's growth plasticity typically overshadows any effect [15] [16]. In our case we observed a considerable reduction in plant dry weight in all three populations. Additionally, by modeling the daily heights of plants from both growing seasons, we could see a reduction in the progression of growth of seedlings from a shortened growing season in all three populations. This suggests that in field conditions, under competition, the negative impact of a shortened growing season on seedling vigor may be enhanced.

Previous studies demonstrated that spring emerged jointed goatgrass, presumably having a shortened vernalization period, produce fewer seed than fall emerged plants [2]. A common generalization in plant reproductive ecology is that plants express large differences in reproductive output primarily through variation of seed number, rather than seed weight [17] [18]. Comparative studies of seed size effects on grassland species described a positive relationship on seedling size and recruitment success as seed size increased [19]. Our observations, coupled with the findings of Fandrich and Mallory Smith [2], indicate that a reduced vernalization period and subsequent shorter growing season influenced seed number and size. Further, seedlings grown from seed produced on maternal plants with a short growing season germinated slower, were shorter, and produced less biomass compared with seedlings grown from seed produced on maternal plants with a long growing season. These results suggest that reductions in the length of the vernalization and growing season affect not only jointed goatgrass fecundity, but also its ability to produced vigorous seedlings.

\section{Conclusions}

The results of this study demonstrate that a shortened growing season negatively affected key attributes of jointed goatgrass seedling vigor: seed mass, percent germination, emergence, and seedling height and biomass, including roots. These early life history events serve as the basis for jointed goatgrass establishment in the field [20]. Therefore, negative impacts on seedling vigor may affect jointed goatgrass early competitive ability, especially during the critical period in the fall when winter wheat and jointed goatgrass germinate and establish. Environmental maternal effects in plants are generally transitory [21] [22], however, and less vigorous jointed goatgrass plants may recover during the resumption of growth in the spring.

A better knowledge of weed ecology can help producers integrate more efficient cultural practices into their weed management strategies [23]. Integration of a number of cultural management techniques, such as planting certified seed, narrow crop row spacing, directed fertilizer placement, controlled fires, and spring crops, has proven to be an effective means of controlling jointed goatgrass [24] [25]. Our research provides greater insight into the timeliness of controlling jointed goatgrass. Controlling fall emerged plants will remove those individuals that have the greatest chance of producing the most vigorous seedlings. Further research is needed to determine if less vigorous seedlings from a shortened growing season are less competitive than those produced under a long growing season.

\section{References}

[1] Morrison, L.A., Cremieux, L.C. and Mallory-Smith, C.A. (2002) Infestations of Jointed Goatgrass (Aegilops cylindrica) and Its Hybrids with Wheat in Oregon Wheat Fields. Weed Science, 50, 737-747. http://dx.doi.org/10.1614/0043-1745(2002)050[0737:IOJGAC]2.0.CO;2

[2] Fandrich, L. and Mallory-Smith, C.A. (2006) Vernalization Response of Field Grown Jointed Goatgrass, Winter Wheat, and Spring Wheat. Weed Science, 54, 695-704. http://dx.doi.org/10.1614/WS-05-069R1.1

[3] Fandrich, L., Mallory-Smith, C.A., Zemetra, R.S. and Hansen, J.L. (2008) Vernalization Responses of Jointed Goatgrass (Aegilops cylindrica), Wheat, and Wheat by Jointed Goatgrass Hybrid Plants. Weed Science, 56, 534-542. http://dx.doi.org/10.1614/WS-07-197.1

[4] Walenta, D.L., Yenish, J.P., Young, F.L. and Ball, D.A. (2002) Vernalization Response of Plants Grown from Spikelets of Spring and Fall Cohorts of Jointed Goatgrass. Weed Science, 50, 461-465. http://dx.doi.org/10.1614/0043-1745(2002)050[0461:VROPGF]2.0.CO;2

[5] Young, F.L., Yenish, J.P., Walenta, D.L., Ball, D.A. and Alldrege J.R. (2003) Spring-Germinating Jointed Goatgrass (Aegilops cylindrica) Produces Viable Spikelets in Spring-Seeded Wheat. Weed Science, 51, 379-385.

http://dx.doi.org/10.1614/0043-1745(2003)051[0379:SJGACP]2.0.CO;2 
[6] Finch-Savage, W.E. (1995) Influence of Seed Quality on Crop Establishment, Growth and Yield. In: Basra, A.S., Ed., Seed Quality: Basic Mechanisms and Agricultural Implications, Food Product Press, New York, 361-384.

[7] Perry, D.A. (1984) Factors Influencing the Establishment of Cereal Crops. Aspects of Applied Biology, 7, 65-83.

[8] Ellis, R.H. (1992) Seed and Seedling Vigour in Relation to Crop Growth and Yield. Plant Growth Regulation, 11, 249255. http://dx.doi.org/10.1007/BF00024563

[9] Burris, J.S., Edje, O.T. and Wahab, A.H. (1973) Effects of Seed Size on Seedling Performance in Soybean: II. Seedling Growth and Photosynthesis and Field Performance. Crop Science, 13, 207-210. http://dx.doi.org/10.2135/cropsci1973.0011183X001300020017x

[10] Grace, J.B. and Tilman, D., Eds. (1990) Perspectives on Plant Competition. Academic Press, San Diego, 484 p.

[11] Fandrich, L. and Mallory-Smith, C.A. (2005) Temperature Effects on Jointed Goatgrass (Aegilops cylindrica) Seed Germination. Weed Science, 53, 594-599. http://dx.doi.org/10.1614/WS-05-03R1.1

[12] Lafond, G.P. and Baker, R.J. (1986) Effects of Genotype and Seed Size on Speed, Emergence, and Seedling Vigor in Nine Spring Wheat Cultivars. Crop Science, 26, 341-346. http://dx.doi.org/10.2135/cropsci1986.0011183X002600020027X

[13] Mian, M.A.R. and Nafziger, E.D. (1994) Seed Size and Water Potential Effects on Germination and Seedling Growth of Winter Wheat. Crop Science, 34, 169-171. http://dx.doi.org/10.2135/cropsci1994.0011183X003400010030x

[14] Black, J.N. (1958) Competition between Plants of Different Initial Seed Sizes in Swards of Subterranean Clover (Trifoliumsubterraneum L.) with Particular Reference to Leaf Area and the Light Microclimate. Australian Journal of Agricultural Research, 9, 299-318. http://dx.doi.org/10.1071/AR9580299

[15] Spilde, L.A. (1989) Influence of Seed Size and Test Weight on Several Agronomic Traits of Barley and Hard Red Spring Wheat. Journal of Production Agriculture, 2, 169-172. http://dx.doi.org/10.2134/jpa1989.0169

[16] Stanton, M.L. (1984) Seed Variation in Wild Radish: Effect of Seed Size on Components of Seedling and Adult Fitness. Ecology, 65, 1105-1112. http://dx.doi.org/10.2307/1938318

[17] Smith, C.C. and Fretwell, S.D. (1974) The Optimal Balance between Size and Number of Offspring. American Naturalist, 108, 499-506. http://dx.doi.org/10.1086/282929

[18] Weiner, J., Martinez, S., Müller-Schärer, H., Stoll, P. and Schmid, B. (1997) How Important Are Environmental Maternal Effects in Plants? A Study with Centaurea maculosa. Journal of Ecology, 85, 133-142. http://dx.doi.org/10.2307/2960645

[19] Jakobsson, A. and Eriksson, O. (2000) A Comparative Study of Seed Number, Seed Size, Seedling Size and Recruitment in Grassland Plants. Oikos, 88, 494-502. http://dx.doi.org/10.1034/j.1600-0706.2000.880304.X

[20] Fleming, G.F., Young, F.L. and Ogg Jr., A.G. (1988) Competitive Relationships among Winter Wheat (Triticum aestivum), Jointed Goatgrass (Aegilops cylindrica), and Downy Brome (Bromustectorum). Weed Science, 36, 479-486.

[21] Miao, S.L., Bazzaz, F.A. and Primack, R.B. (1991) Persistence of Maternal Nutrient Effects in Plantago major: The third generation. Ecology, 72, 1634-1642. http://dx.doi.org/10.2307/1940963

[22] Schmid, B. and Dolt, C. (1994) Effects of Maternal and Paternal Environment and Genotype on Offspring Phenotype in Solidago altissima L. Evolution, 48, 1525-1549. http://dx.doi.org/10.2307/2410246

[23] Anderson, R.L. (1998) Ecological Characteristics of Three Winter Annual Grasses. Weed Technology, 12, $478-483$.

[24] White, A.D., Stahlman, P.W. and Northam, F.E. (2004) Impact of Integrated Management Systems on Jointed Goatgrass (Aegilops cylindrica) Populations. Weed Science, 52, 1010-1017. http://dx.doi.org/10.1614/WS-04-077R

[25] Young, F.L., Ball, D.A., Thill, D.C., Alldrege, J.R., Ogg Jr., A.G. and Seefeldt, S.S. (2010) Integrated Weed Management Systems Identified for Jointed Goatgrass (Aegilops cylindrica) in the Pacific Northwest. Weed Technology, 24, 430-439. http://dx.doi.org/10.1614/WT-D-10-00046.1 